\title{
Continuing Training until End-of-Carreer: A Key Policy for the Fourth Pillar*
}

\author{
by Geneviève Reday-Mulvey**
}

\begin{abstract}
"Fixed retirement ages are likely to disappear as the demographic deficit hits the labour market, as improving health standards extend the life span, and as the costs of pensions become unbearable for the active work force.

The age period 45 to 55 could well become a period of re-skilling and retraining. "
\end{abstract}

H. J. Jones, Director of the Task Force Human Resources, Education \& Training, EC.

\section{Introduction: The context or the logic of continuing training until-end-of career}

The Geneva Association, when in 1987 it launched its research programme on Work and Retirement (called the "Fourth Pillar"***) had as a central idea the need to rethink the role in our society of older workers - a majority of whom are in good physical and mental health - and to develop the notion that an ageing population can be a "blessing" if we are ready to transform "problems" into "opportunities".

The constraints are twofold: demographic and financial. I will not dwell upon them since they are common knowledge. The acute ageing of our population obliges us today to reconsider the economic and social contribution of "retired people" to our service economy in the decades to come. This ageing, indeed, will be putting enormous pressure on pension funding at the beginning of next century, a fact that has recently led several governments (USA, Gerinany, France, Italy, the UK and in June 1994 even Sweden, etc.) to change legislation on public pensions and to raise the age of retirement or increase the number of contribution years to social security. Fortunately, the transition from an industrial to a service economy is producing increasingly flexible work options in terms of time and space. Almost $40 \%$ of jobs in a number of countries (Scandinavia, Holland, UK, USA, etc.) are now flexible in form: part-time, self-employment, gradual retirement, temporary work, etc., and this trend appears to be widening.

Moreover, more and more jobs have a high mental content, and scientific studies have shown that mental capabilities remain viable late in life. On the other hand, sociological surveys have also shown that workers of the baby-boom generation may well desire another pattern for "life after 60 " involving more especially work on a part-time basis, and a more flexible life-cycle.

* This article is based on a paper delivered at the International Carnegie Conference in London, April 28-29, 1993.

** Social economist, chargée de recherche, The Geneva Association.

*** The first pillar is defined as the basic, usually social security, pension; the second pillar as the occupational pension; the third pillar as an individuals' savings and investment; the fourth pillar, strico sensu, is the option open to more and more qualified workers after the age of 60 years to continue employment on a part-time basis in combination with a partial pension. 
Currently two opposing trends may be observed:

a) A traditional trend, still prevalent in industrialised countries, which asserts that older workers should make room for younger people. Many programmes and incentives still support this trend although, in most OECD countries, the age limit for access to early retirement has been raised over recent years and the terms of early retirement compensation have been made less attractive by governments. Early retirement policies, though at one time felt to be necessary, are beginning to prove inadequate.

b) A new trend which has emerged over the last five years calls for a flexible extension of working life and a more active role for older people in society. Today's elderly seem to be much younger than were their parents at the same age; they are better educated, better informed, more flexible, more interested in the world around them and more willing to learn than people of the same age just 20 years ago. As their number increases significantly - and as that of young labour force entrants decreases - the influence of older people on society, on institutions and particularly on firms will grow. A main feature of the reformed legislation on public pensions is that it encourages or obliges people to prolong their working lives. Such legislation also requires a complete reappraisal of the role of older workers in business. Meanwhile, in a more general way in our societies, some of the established myths regarding the limitations of the older worker are beginning to disappear. This new trend towards a flexible extension of working life is already developing in spite of the current high level of unemployment. But even if that level remains high, older workers, for financial and demographic reasons, will not be able to retire as early as most do now. Should, however, there be a significant reduction in unemployment, older workers will be in increasing demand on the labour market.

The Carnegie Inquiry* in Great Britain, as well as the various studies undertaken or supported by the Geneva Association in the UK, France, Germany, the USA and Japan, have all established one fact beyond doubt : if older workers are to remain competitive, productive, motivated and flexible, they will need continuing training until the end of career. Continuing education and training, while by no means the solution to ail problems facing older workers, will doubtless prove to be the key to older people remaining professionally integrated and active in the community.

\section{Education and training for older workers and people: products and providers}

Although this paper focusses on continuing training (in service) as a main policy to preserve employment for workers in their fifties, in order to give an idea of the general context we list here products and providers of education and training for older workers and people, and make a few comments on these.

General further education for older people has developed very much over the last tenfifteen years in most Member States, but it is very uneven not only between countries but inside each of them. Obvious examples are the University of the Third Age, now often rebaptised Open University, University for All or University of Leisure, fairly developed in

* See "Life, Work and Livelihood in The Third Age", Final Report, The Carnegie Inquiry into The Third Age, London, 1993. 


\section{Products}

1) Continuing in-service training until-end-of-career

2) Specific training or re-training for various target categories:

- long-term unemployed

- those changing from full career to selfemployment

- those leaving declining industries

- those willing to work for volunt. organisations

- etc.

3) General (i. e. non-vocational) further education eg. Uni 3A, Open University

4) Pre-retirement education

5) Raising public awareness of the change in the life-cycle and of the consequent revaluation of the place of Third Agers in the economy and community.

eg. 1993 Year of Older People and Solidarity.

\section{Providers}

Employers:

Firms and Public Sector

Government

Educational Institutions

(Public and Private)

Employers :

Firms and Public Sector + Vol. Org.

Media, government

countries like Belgium and France. As a general rule, further education is much more common in Northern countries (Denmark, Holland, UK), and to a certain extent Germany, than in southern countries.

Despite a promising start in the 50 s in the UK, and ten years later in other Member States, preparation for retirement has made little headway in Europe, in terms of the number of people it reaches (about $10 \%$ only) and the form it takes. Despite new impetus in the 1970s, as the Third Age became more visible and retirement acquired a more positive image, the groundswell of interest which emerged throughout Europe in the late 70s has not developed into an effective movement. According to a 1992 survey, in Germany, pre-retirement education is not provided by the majority of large firms and by only $14 \%$ of mediumsized firms (from 100 to 1'000 employees). All experience by companies and further education institutions shows that the initial participation problems dwindle once the courses in the companies have become an everyday event and the participants no longer feel themselves to be in a special role. However, as in most countries, early retirement policies have had a negative effect on pre-retirement education since workers who leave early feel they are too young to be participating in a pre-retirement course.

Given the enormous potential demand for these various forms of education and training, the problems of meeting that demand might seem daunting. The ground in EU 
Member States is littered with half completed programmes or reforms and even, in some cases, of complete failures. But, according to $\mathrm{H}$. C. Jones, what is required at this stage is a model - a "systemic approach" - for education and training until-end-of-career:

"We can take heart if we realise that a systemic approach does not mean a single monolithic system approach managed from the top. What we need is a coherent set of opportunities to be flexible available at different points in the life-cycle. It is not a formal education and training system based on the separation between generations, but new relationships between existing structures so that they help individuals to make the needed adjustments and constitute a "portfolio of competences".

\section{Continuing training and education: The statutory position}

This review of statutory provisions at the International, European and National levels is brief since so far little exists:

- At the International level

Legislation is confined to ILO Recommandations:

- No. 162 (1980 - The Older Workers Recommandation) spells out the principles of, and provides guidance for, national policy as regards older workers.

The recommanded measures have 3 main objectives:

- prevention of discrimination in employment and training,

- increased social protection,

- preparation for, and access to, retirement.

- No. 169 (1984 - The Employment Policy Recommandation) invites Member States to respond to the needs of older workers having difficulties in finding lasting employment.

But, as far as training and education for older workers specifically are concerned:

- No. 150 (The Human Resource Development Recommandation), adopted as early as 1975, called on Member States to implement specific measures to "provide older workers with the vocational guidance and training they need with special reference to:

- Updating of knowledge and skills: - upgrading of the level of general education and occupational qualifications; - the provision of appropriate further training: - availability of suitable posts: - avoidance of unrealistic age limits; - provision of age-specific methodology; - provision of competent instructors: - promotion of training for older workers: - education of the general public on the need for training."

Research: The ILO is currently carring out an important programme of research on training and education for older people (see reference to this Programme at this end of this paper).

\section{- At the European Union level}

As yet, there exists no overall education and training policy for older people. However, there is:

- A Recommandation of 10 December 1982 on a Flexible and Gradual Retirement. This recommandation establishes both the principle of pre-retirement programmes as well as that of the entitlement to work after pension age. A Report (18 December 1992 by the Commission of the EC) shows to what extent these recommandations have been implemented in Member countries. In Germany, Belgium, Italy, Spain, France and Luxembourg new laws have been passed promoting more gradual and flexible retirement. Significantly. 
the Report also calls for the promotion of work for "retirees" and an extension of working life, which implies the need for more training and education of older people and workers.

- A Council Decision of 29 May 1990 on the Development of Continuing Training in the European Community (Programme Force) which establishes the principle of access, and the right to access, to continuing vocational training throughout one's working life.

- The Maastricht Agreement (Art. 127) provides for Commission competence in the matter of Training.

One of the stated objectives of the 1993 Year of older people was the promotion of an EU policy on education and training for the European Communities' ageing population. Research : FORCE in Brussels and the CEDEFOP (European Centre for the Development of Vocational Training) in Berlin are currently carrying out research on training and education throughout the life span (sce references at the end of this paper).

- As far as national policies are concerned, it can be stated that government regulations tend to favour pre-retirement cducation. There are, however, a number of measures regarding training or re-training of unemployed workers after the age of 45 or 50 years.

There exist very few examples of laws, recommandations or government incentives favouring training for older workers specifically. One Example is the French Law of 2.8.89 which contains, among other measures for older workers, a provision on the funding of training after the age of 45. Another example can be found in Germany in the Employment Promotion Act of 1969 (amended in 1987) which refers to the integration of older workers and which stresses the need to promote participation in continuing training programmes. The implementation of these provisions has been entrusted to a Government body, the German Office of Labour.

\section{Continuing training and education: Case studies}

In spite of the current recession, in some EU Member States and OECD countries, public and company policies and programs are being set up to promote training and education until-end-of-career. Some of them are targeted towards older workers or people, others - as in Sweden - clearly reflect the principle that education and training are a lifelong process. Although there are excellent examples of programmes in most EU Member States, there is not yet one country which has a global policy. That is why I have chosen to present, along with France, the example of Japan as, perhaps, being the only country in the OECD which has so far set up a global policy.

\subsection{Continuing training until end-of-career in Firms: France}

It is well known that in France continuing training has enjoyed a legal basis since adoption of the Law of April 1971: since then, firms - except those with less than 10 employees - must spend a proportion of their wage mass on continuing training activities inside or outside the firm; from an initial $0.8 \%$, this rose to $1.5 \%$ in 1993 . Since 1992 , another law obliges small firms (with less than 10 employees) to spend $0.15 \%$ of their wage cost on training.

Overall, in 1991, firms (of 10 or more employees) spent over $3 \%(3.2 \%)$ on training, that is, 40 billion FF. In this context, continuing training was provided to $39 \%$ of salaried workers in this category of firm or to 3.57 million people, who on average received 48 hours of training per ycar. 
Older workers tend to receive less training than younger ones. However, recent statistics show that the gap in the training between workers after the age of 45 and workers before this age has been narrowing over the last five years. In 1992, in firms of over 10 employees, employees aged 45 and over accounted for $24 \%$ of employees and $21 \%$ of trainees.

There are three explanations for this positive development: first, continuing training appears be strongly related to cohort effects; secondly, and more important, over the last few years, more and more large firms have devised good training programmes suited to the needs of an ageing work force. And thirdly, government policy has tried to slow down early retirement.

Indeed, several laws and measures appear to be moving in the right direction:

- the law of August 21989 provides for the funding of CT of employees over the age of 45 ; it is completed by a measure of 18 January 1991 ;

- a law of 1987 has raised the cost of laying-off employees over 55 years of age (though there are still many exceptions);

- a law of December 1989 facilitates the recruitment of the victims of long-term unemployment after 50 years by exempting the enterprise of all social insurance contributions until such time as the employee becomes eligible for a full retirement pension;

- the decree of 11 September 1989 encourages part-time employment as a substitute for lay-offs on economic grounds;

- a law of 5 January 1988 promotes tapered retirement by entitling an employee of 60 years old to receive a partial pension while continuing to work part-time with no age limit set for full retirement;

- a measure of February 1993 provides for modest financial incentives for the training and work organisation of older workers;

- a number of sectorial agreements between trade-unions and employers are having a positive impact on continuing training after the age of 45 .

According to interviews in 1993 in a number of dynamic, and for the most part, large firms, there is a trend towards extending continuing training until-end-of-career.

I will focus here only on the example of insurance companies. The large ones, such as UAP, AXA, AGF, GAN, are currently devising excellent programmes for employees in the second part of their career. These companies spend 5 to $8 \%$ of their wage mass on continuing training. Since the majority of employees in insurance spend most of their career in the same company, two objectives are crucial: 1) to encourage internal mobility by providing training not only with a skills content, but also with a psychological dimension (improved communication and social skills); and 2) to increase the general knowledge and skills of averagely skilled employees by a training programme of a minimum of 400 hours. The latter objective is essential since skills requirements in insurance have radically altered in recent years. Even if this training mainly concerns employees aged 40 and over, it is not so much age-specific; it is rather part of an overall endeavour to keep work methods, skills and motivation adjusted to enterprise requirements throughout an employee's career up to the age of 62 .

Examples of good continuing training practice exist in a number of sectors; we can cite l'Aérospatiale, BSN, Hewlett-Packard, Thomson, Renault, Manducher, all of which currently adapt their training and work conditions to a rapidly ageing work force. 
According to a recent report * by Entreprise et Progrès what is needed at this point is certainly a policy of continuing training to cover the entire career-span but also a global policy for end-of-career management. The Report points to some interesting strategies that have already been tried by a number of firms and which doubtless are destined to be developed further over the next few years:

Strategy 1 - The employee becomes the manager/builder of his own career while the enterprise provides the design and architecture within which this can take place

The sort of end-of-career problems that tend to crop up around 55 years should in the normal course of events have been foreseen and catered for several years previously. For it is when the wage-earner reaches around forty that questions about the future role he is going to play within the enterprise that has employed him (as also outside) should begin to be asked. Prospective staff management techniques are not designed to produce job security "per se" but rather the added human-resource value of constantly updated skills buttressed by experience. The principal tools of such management are 3 in number; the training plan, the skills and aptitudes review, and the assessment centre. Enterprises that to date have made use of these new tools - at least those surveyed in France - declared themselves most satisfied with the results.

\section{Strategy 2 - The development of new flexibilities in organising work}

First and foremost, flexibility in working conditions. A number of undertakings, and increasingly so in France, have begun to reduce the workhours of their employees as of 5658 years, a process which continues until full retirement age is reached. This is known as gradual or progressive retirement. Rhône-Poulence, UAP, AXA, Renault, BTP are some French examples of firms which are starting to apply this practice, with two of them having successfully converted some reduced-time jobs into tutorships. Others (e.g. Evian, Dassault).

Meanwhile, with manual workers, experiments have been conducted (e.g. Renault, Aérospatiale) to introduce modern ergonometric techniques into the workplace and to deploy workers in a differenciated and positive fashion until retirement age.

Other kinds of flexibility are currently under discussion and study; among them job sharing at end-of-career and work which is, in part at least, performed at home. Neither of these flexibility options is without special problems, and yet once the initial steps have been taken, they often prove to be a source of savings for the employer and of considerable satisfaction for both parties. There are yet other forms of flexible work organisation. One which seems to have caught on particularly in the UK is the use of "skills or expertise pools". Pools of expert employees are held in reserve and receive a substantial portion of their wage from the enterprise which employed them. At the same time, they perform functions as assistants and/or consultants to various public bodies and to voluntary associations.

\section{Strategy 3 -Modifications to the wage-and tax-régimes of end-of-career employees}

Any move to promote flexible extension of working life must not only focus on preserving the motivation and productivity of employees right up to full-retirement age but must of necessity also take a very close look at their salary conditions. Some of the traditional seniority-related parameters are now under very serious scrutiny in certain countries

\footnotetext{
* La gestion des fins de carrière, B. Reumaux, Entreprise et Progrès, Paris, 1993.
} 
and sectors (e.g. Insurance in France). For it is only natural that schemes which, through reduced work hours, enable the end-of-career employee to function at a pace more suited to his or her age must, at the same time, in spite of the high skills and expertise possessed, make those employees less expensive.

\subsection{Recent European Research}

According to a recent survey of 30 large companies in 5 Member States (France, UK, Netherlands, Belgium and Spain) done by the CEDEFOP, the large majority of these companies are changing their attitudes towards training and employee participation. Since over the last few years, they have been recruiting few young workers and the median age of their employees is rapidly increasing, they see the urgent need of integrating employees in the process of raising the quality of work organisation and of products with stronger participation of the staff in the relevant decision-making processes. Most them spend over $5 \%$ of the wage mass on training and qualified workers until-end-of-career are integrated in continuing training. Another study on a greater number of firms in 9 Member States is currently being carried out. According to the CEDEFOP, German firms, especially large ones, spend enormous resources on continuing training, probably more than French firms, but no overall statistics appear to exist. According to some sources, the private sector appears have spent DM 27 billion on continuing training in 1987. Firms such as Siemens, VW, Daimler Benz, for example, are cited for their considerable efforts. But according to experts interviewed, in spite of some interesting cases, there is not yet a trend in German firms to extend continuing training until-end-of-career. Although it is premature to make such a statement, it would appear that Danish and some large Dutch firms are perhaps the most advanced as far as the design of training and education as a life-long process is concerned.

\subsection{A more global policy: Japan}

There appear to be 3 main reasons why Japan has already felt the need for defining a more global policy than other industrialised countries: a persistent labour shortage, a work ethic which places a premium on working late and on continuing training and education, and the pace of technological innovation.

The Government has supported the employment and training of older workers in several acts and laws:

- 1986: the Law Concerning the Stabilization of Employment for Older Workers, which includes the promotion of continued employment up to the age of 60 , the promotion of reemployment of "retired workers", and assistance in preparation for retirement and job placement ;

- the Revised Pension Bill which became a Law in 1989;

- the Occupational Skill/Ability Development Act which set aside a certain portion of training activities for older workers $(45+)$ and a higher rate of cost reimbursement for training older workers. If the workers get training outside the firm, $50 \%$ of costs are reimbursed.

The Government has offered various financial incentives and aids to companies with good practice. Perhaps too early to judge, it is thought that vocational training and education of older workers are currently developing fast. About three companies out of 10 $(30.1 \%)$ include "career development programs" in their practices for older workers in the company: $43.5 \%$ in companies with more than 3 '000 or more employees, $27.2 \%$ in those with less than $1^{\prime} 000$ employees. As elsewhere, larger companies tend to encourage training 
or retraining more than small companies which, however, in Japan receive larger subsidies than big firms. Career development programs include: career development training, job rotation, pre-retirement vocational training, and long-term training holidays. Regarding, specifically, job-training for older workers, more than a fourth of companies $(28.2 \%)$ provide this training, and in large companies (over 1'000 employees) $55.3 \%$ are practicing it. The Unions in Japan also set great store by the need for training an ageing work force, and have already presented two reports (in 1986 and 1987) on this issue and organised a wide range of courses and training programmes.

\section{REFERENCES}

Carnegie Inquiry into The Third Age, 3 Robert Street, London WC2 6BH.

ILO: Training Policies Branch, 4 route des Morillons, 1211 Geneva 22, Switzerland.

Tel. (41-2) 7996908 , Fax (41-22) 7988685.

FORCE: Task Force for Human Resources, Continuing Training Department, 220 rue de la Loi, B-1049 Brussels. Tel. (32-2) 29592 38, Fax (32-2) 2955699.

CEDEFOP: European Centre for the Development of Vocational Training, Jean Monnet House, Bundesallee 22, D-1000 Berlin. Tel. (49-30) 8841 20, Fax (49-30) 88412222.

Salariés Agés: Conditions de travail et transition vers la retraite, Rapport sur la France pour le Bureau International du Travail, X. Gaullier \& A. Goldberg, Genève, 1993.

The Transition from Work to Retirement, Report on Japan, OECD, 1991, Paris. 